\title{
Insulin-Degrading Enzyme
}

National Cancer Institute

\section{Source}

National Cancer Institute. Insulin-Degrading Enzyme. NCI Thesaurus. Code C112878.

Insulin-degrading enzyme (1019 aa, $118 \mathrm{kDa}$ ) is encoded by the human IDE gene. This protein is involved in the metabolism of bioactive peptides. 